山村 行夫*, 山村 恵彦*, 吉田 稔*

\title{
MERCURY CONCENTRATION IN BLOOD AND URINE OF WORKERS IN SMALL PLANTS MANUFACTURING MERCURIAL THERMOMETERS
}

\author{
Yukio YAMAMURA ${ }^{\dagger}$, Shigehiko YAMAMURA ${ }^{\dagger}$ and Minoru YOSHIDA ${ }^{\dagger}$
}

\begin{abstract}
The results of our study on the method of evaluating mercury in man's urine and blood with reduction-aeration procedure are reported in this paper as well as the results of our investigation on chronic mercurial poisoning in workers employed by a small-scale manufacturer of thermometers.

1. Mercury in the urine was determined in the following way. Add excess cystein and stannous chloride to the urine sample, and then alkalize this mixture with $\mathrm{NaOH}$ solution. Take the resultant mercurial vapor into a quartz absorption cell and evaluate with the atomic absorption spectrophotometer. With this method it was possible to detect as small an amount as $0.05 \mu \mathrm{g}$ of mercury in the sample and this procedure proved to be much simpler than others and the results obtained were less variable than those obtained with the method which involved oxydation of the sample urine with potassium permanganate.

2. Mercury in the blood was determined by the following procedure. About $10 \mathrm{~g}$ of the whole blood was deproteinized three times with $20 \mathrm{~m} l$ of cystein being given 5 per cent trichloroacetic acid. This makes the mercury to be extracted. The supernatant of this was used as a test sample, and the mercury was determined with stannous chloride and $\mathrm{NaOH}$ solution as in the case of mercury evaluation of the urine. The recovery rate of mercury with this method was 100 per cent.

3. The amount of mercury in the urine samples taken from normal subjects was in an average $3.5 \pm 2.3 \mu \mathrm{g} / l$ and the amount of mercury in the blood samples of normal subjects averaged $0.9 \pm 0.6$. $\mu \mathrm{g} / 100 \mathrm{~g}$.

4. Of 47 workers of investigated 14 factories manufacturing mercurial thermometers of ordinary type, 13 subjects showed more than $300 \mu \mathrm{g} / l$ mercurial content in the urine and 5 subjects showed the blood values over $10 \mu \mathrm{g} / 100 \mathrm{~g}$. Two subjects showing a high level of mercurial content in the blood had such signs of chronic mercurial poisoning symptoms as tremor and scanning speech.

5. In five factories manufacturing special type of mercurial thermometers, such as maximum and minimum thermometers, Beckman's differential thermometers, dial thermometers, etc., there was no subject that showed more than $300 \mu \mathrm{g} / l$ mercurial content in the urine. However, in some of the workers who had served long years the blood showed values over $10 \mu \mathrm{g} / 100 \mathrm{~g}$ in mercurial content.
\end{abstract}

\section{緒言}

水銀温度計製造業から慢性水銀中毒が散発的に報告さ れていることは, 今日でもな和潜在的発生はかなり存在 することが推測される1,2).

温度計製造業はきわめて零細な規模のものが多く, そ

*東洋医科大学公衆衛生学教室

昭和 47 年 7 月 22 日受付

tDepartment of Public Health, Toyo Medical College

$\mathrm{R}$ eceived for publication, July 22, 1972

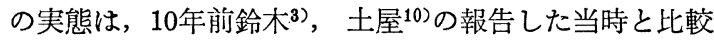
し，水銀填め作業に改善がみられるほかはあまり变わっ ていない, これら製造業者は, 主人一人, 夫婦, 親子と いった家内工業が多く, 作業場の隣室では家族が起居す る例も多い, 従業員がいる場合でも数名程度の小企業で ある.

これら製造業者は, 相互の連携が十分でなく, 労衝衛 生知識の普及もあまり浸透していない実状にある.

今回, 東日本硝子製温度計工業組合員名簿を手に入れ たため, 各個々の業者に協力を要請し, 調査に応じた19 
Table 1. Mercury concentration in blood and urine of workers and their symptoms.

\begin{tabular}{|c|c|c|c|c|c|c|c|c|}
\hline Maker & Subject & Sex & Age & $\begin{array}{l}\text { Period } \\
\text { (year) }\end{array}$ & $\begin{array}{c}\mu \mathrm{g} . \mathrm{Hg} / \\
\text { liter urine }\end{array}$ & $\begin{array}{l}\mu \mathrm{g} . \mathrm{Hg} / \mathrm{g} \\
\text { creatinine }\end{array}$ & $\begin{array}{c}\mu \mathrm{g} . \mathrm{Hg} / \\
100 \mathrm{~g} \text { blood }\end{array}$ & Symptoms \\
\hline \multirow[t]{4}{*}{ A } & employer & M & 58 & 30 & 1,098 & & 37.7 & Tremor $(+)$, Scanning Speech $(+)$ \\
\hline & family & $\mathbf{M}$ & 28 & 10 & 670 & & 11.4 & \\
\hline & family & M & 26 & 8 & 200 & & 15.6 & Gly cosuria (HI) \\
\hline & family & $\mathrm{F}$ & 21 & 2 & 214 & 760 & 16.7 & Glycosuria (H) \\
\hline \multirow[t]{10}{*}{ B } & employee & $\mathbf{M}$ & 42 & 16 & 1,945 & 916 & 17.2 & \\
\hline & employee & M & 55 & 35 & 1,159 & 709 & 15.9 & \\
\hline & employee & M & 42 & 19 & 1,409 & 814 & 16.3 & Albuminuria $( \pm)$ \\
\hline & employee & M & 53 & 12 & 973 & 1,214 & 13.4 & Albuminuria $( \pm)$ \\
\hline & employee & M & 56 & 21 & 1,418 & 788 & 19.1 & Albuminuria $( \pm)$ \\
\hline & employee & M & 59 & 12 & 373 & 295 & 5.8 & \\
\hline & family & $\mathrm{F}$ & 43 & & 177 & 493 & 8.8 & \\
\hline & family & $\mathrm{M}$ & 30 & 21 & 541 & 215 & 9.0 & \\
\hline & family & $\mathrm{F}$ & & & 56 & 29 & 3.1 & \\
\hline & employer & $\mathrm{M}$ & & & 45 & 27 & 4.0 & \\
\hline \multirow[t]{3}{*}{$\mathrm{C}$} & employer & $M$ & 43 & 15 & 300 & 258 & 13.0 & \\
\hline & housewife & $\mathrm{F}$ & 41 & 10 & 336 & 270 & 15.7 & \\
\hline & employee & $\mathrm{F}$ & 41 & 3 & 71 & 46 & 4.9 & \\
\hline \multirow[t]{3}{*}{$\mathrm{D}$} & employer & M & 59 & 27 & 116 & 185 & 27.8 & $\begin{array}{l}\text { Tremor }(+) \text {, Scanning Speech }(+) \\
\text { Albuminuria }(+) \text {, Glycosuria }(+)\end{array}$ \\
\hline & housewife & $\mathrm{F}$ & 41 & 20 & 84 & 178 & 7.6 & \\
\hline & family & M & 22 & 4 & 259 & 180 & 10.7 & \\
\hline \multirow[t]{3}{*}{$\mathrm{E}$} & employer & $M$ & 43 & 20 & 125 & 128 & 5.4 & \\
\hline & employee & M & 37 & 22 & 205 & 303 & 6.3 & \\
\hline & housewife & $\mathrm{F}$ & 40 & 3 & 95 & 122 & 4.1 & \\
\hline F & employer & M & 49 & 34 & 241 & 328 & 13.0 & . \\
\hline \multirow[t]{3}{*}{ G } & employer & $\mathrm{M}$ & 36 & 12 & 179 & 144 & 7.2 & \\
\hline & family & M & 29 & 12 & 307 & 216 & 13.4 & \\
\hline & housewife & $\mathrm{F}$ & 29 & 7 & 93 & 57 & & \\
\hline \multirow[t]{3}{*}{$\mathrm{H}$} & employer & M & 68 & 55 & 141 & 239 & 5.1 & Scanning Speech $( \pm)$ \\
\hline & family & $\mathrm{M}$ & 38 & 18 & 326 & 253 & 4.8 & \\
\hline & family & M & 31 & 12 & 246 & 289 & & \\
\hline I & housewife & $\mathrm{F}$ & 43 & 13 & 168 & 166 & 10.9 & Albuminuria $(+)$ \\
\hline \multirow[t]{3}{*}{$\mathrm{J}$} & employer & M & 53 & 30 & 200 & 196 & 7.8 & Albuminuria $(+)$ \\
\hline & employee & M & 52 & 15 & 174 & 743 & 5.7 & \\
\hline & employee & M & 66 & 27 & 174 & & 5.6 & \\
\hline $\mathrm{K}$ & employer & M & 37 & 20 & 173 & 589 & 5.9 & \\
\hline $\mathrm{L}$ & family & M & 29 & 11 & 32 & 39 & 4.7 & \\
\hline \multirow[t]{4}{*}{ M } & employer & M & 67 & 30 & 91 & 125 & 5.8 & \\
\hline & employee & M & 45 & 7 & 174 & 325 & 9.9 & . \\
\hline & employee & M & 48 & 7 & 65 & 49 & 2.2 & \\
\hline & employee & M & 25 & 3 & 76 & 51 & 3.9 & Glycosuria（H） \\
\hline \multirow[t]{3}{*}{$\mathrm{N}$} & employee & M & 48 & 20 & 700 & 155 & 5.1 & Albuminuria $( \pm)$ \\
\hline & employee & $\mathrm{M}$ & 51 & 20 & 434 & 137 & 4.2 & \\
\hline & employee & $M$ & 64 & 20 & 349 & 120 & 6.5 & Albuminuria $( \pm)$ \\
\hline
\end{tabular}




\begin{tabular}{l|l|l|l|c|r|r|r|r}
\hline & employee & $\mathrm{M}$ & 50 & 10 & 149 & 103 & 4.0 & \\
$\mathrm{O}$ & employee & $\mathrm{M}$ & 42 & $1.2 \sim 13$ & 167 & 165 & 3.7 & \\
family & $\mathrm{M}$ & 24 & $2 \sim 3$ & 387 & 231 & 6.0 & \\
family & $\mathrm{M}$ & 27 & 7 & 314 & 168 & 3.4 & \\
$\mathrm{P}$ & employer & $\mathrm{M}$ & 55 & 30 & 78 & 39 & 5.0 & \\
$\mathrm{Q}$ & housewife & $\mathrm{F}$ & 49 & 35 & 102 & 35 & 3.9 & \\
$\mathrm{R}$ & employer & $\mathrm{M}$ & 37 & 20 & 56 & 70 & 2.4 & \\
$\mathrm{~S}$ & employer & $\mathrm{M}$ & 46 & 30 & 46 & 124 & 12.6 & \\
& employer & $\mathrm{M}$ & 46 & 30 & 61 & 85 & 8.9 & \\
\hline
\end{tabular}

$\mathrm{A} \sim \mathrm{N}$ Mercury filled thermometer makers.

O Mercury filled, enclosed white glass scale, thermometer maker.

$P$ Maximum \& minimum thermometer maker.

$\mathrm{Q} \sim \mathrm{R}$ Beckmann differential thermometer makers.

$\mathrm{S}$ Dial thermometer maker.

業者についての水銀暴露に伴ら健康診断を実施したの で，尿中・血中水銀值を中心報告する.

\section{調 查 方 法}

1. 調査対象

調査対象の温度計製造業者は Table 1 亿示すように, (A) 〜 ( N ) 飞水銀棒状温度計と浾液棒状温度計が主な製 品である. 作業者の構成は, 主人一人, 夫婦, 親子を中 心に若干の従業員が加わるごく小規模の業者である.月 間水銀使用量は個々の箘者で羑が著しいが, $10 \mathrm{~kg}$ を越 学ることは少ない，しかし，次の特殊型水銀温度㖕製造 業よりは使用量が多く, 作業環境は一般に悪く, したが って測定成績も異常值が目立つ.（O)〜 ( S ) の業者は, “特殊もの”といわれ, 水銀二重管温度計, ベックマン 温度計, 隔測温度計などの小企業製造業者である.

経験年数は, 被検者のすべての人が温度計製造を唯一 の職業としていることを示す。

製造業者の主婦の場合，結婚前にすでに水銀作業の職 業歴をもつものが多く, したがって経験年数も比較的長 いのが特微である。

調査は，被検者について，慢性水銀中毒に関する視診 と調查時にスポット尿と採血を行ない，尿中無機水銀濃 度測定, 血中無機水銀濃度測定, ヘマコンビテックスに よる尿検查を実施した。

調查は, 昭和 47 年 5 月 22 日から昭和 47 年 6 月 28 日まで の間に行なった。

2. 尿中・血中無機水銀測定法

日立製207型原子吸光分光光度計に日立製 207-0253

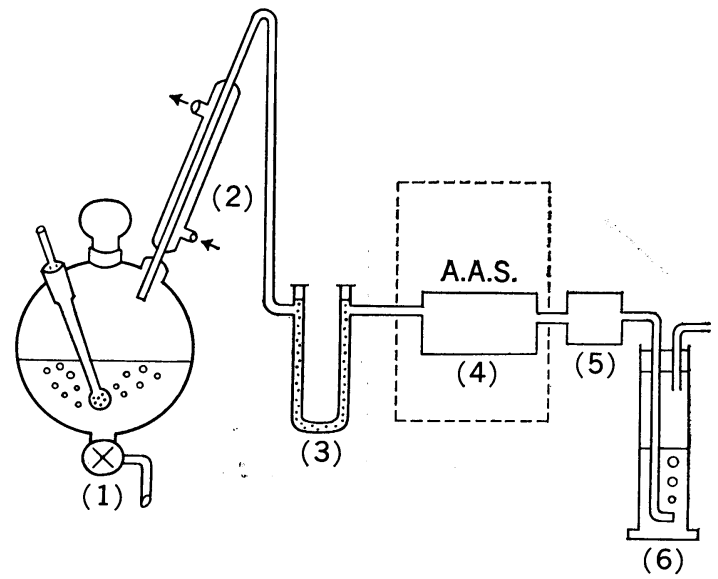

Fig. 1. Schematic diagram of the apparatus.

(1) reaction flask, (2) condenser, (3) drying tube containing silicagel, (4) detecter, (5) $\mathrm{KMnO}_{4}$ absorber, (6) drain, A. A. S. : Atomic Absorption Spectrophotometer.

$\mathrm{Hg}$ ガスセルを装垻し, 還元気化装置を用いて測定した. 還元気化装置をFig. 1 亿示す. 測定波長 $2537 \AA$ ○゙ある. 測定は, Magos \& Cernik 法年を一部改良して行なっ た.
(a) 試 薬
1） $1 \%$ システイン液 $\left(1 \mathrm{~N}-\mathrm{HNO}_{3}\right.$ に溶解).
2) $10 \%$ 塩化第 1 錫液 $(0.5 \mathrm{~N}-\mathrm{HCl}$ 溶解).
3) $30 \% \mathrm{NaOH}$ 液.
4） $1 \%$ \%システイン添加 $5 \%$ \%リクロル酶酸液（血液 除蛋白用). 
5）脱イオン再蒸溜水. 試薬はすべて SSG または SG 規格のものを用いる.

6）水銀基準液 市販の $1 \mathrm{ppm}$ 基準液（和光純薬製） から $1 \mu \mathrm{g} / \mathrm{m} l$ 液を調整する.

(b) 尿中無機水銀の測定

水銀作業者では, 尿 $1 \sim 5 \mathrm{~m} l$ を再蒸溜水で $100 \mathrm{~m} l$ に 稀釈し, 検液とする. 正常尿では $100 \mathrm{~m} l$ を用いる. 本 法では, ガスセル中の水銀蒸気濃度を測定するため, 試 料の液量は一定にする必要がある. 還元気化器に尿稀釈 液 $100 \mathrm{~m} l$ を入れ, 次に $1 \%$ システイン液 $10 \mathrm{~m} l$, 塩化第 1 錫液 $10 \mathrm{~m} l, 30 \% \mathrm{NaOH}$ 液 $10 \mathrm{~m} l$ の順で加兄, 上栓 をし, エアレーションを開始する. 数秒後, 記録計の指 針は上昇を示す．指針がピークに達した点を測定点とす る. 各測定時には同一条件で, 盲検と, $1 \mu \mathrm{g} / 100 \mathrm{~m} l$ 標 準液についての測定を行なら，測定後は指針が 0 点に戻 るまで水洗を続ける．針が戻りにくい場合はシリカゲル を交換する。

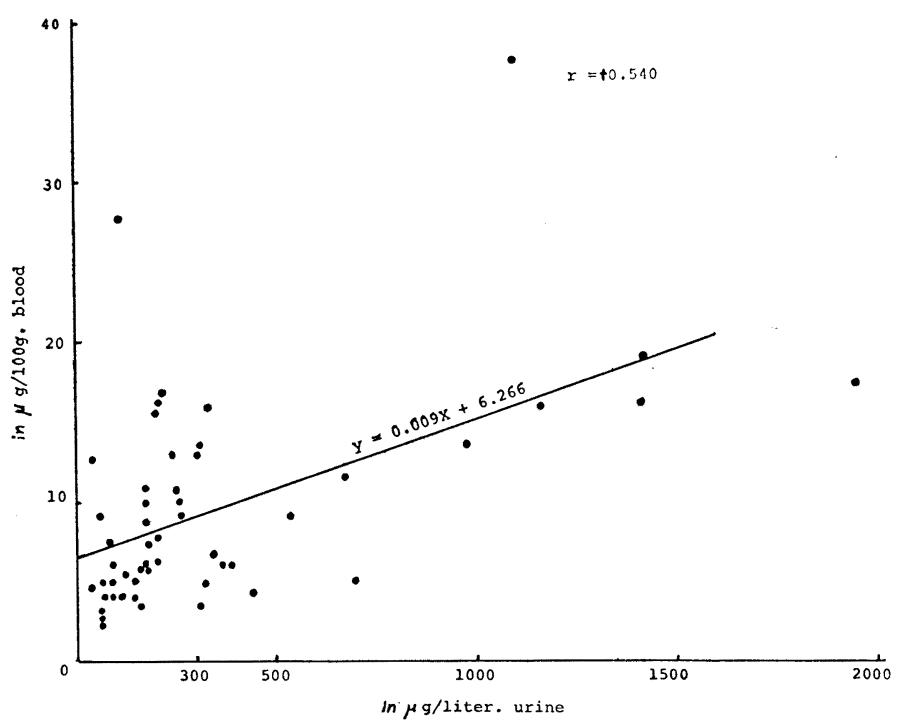

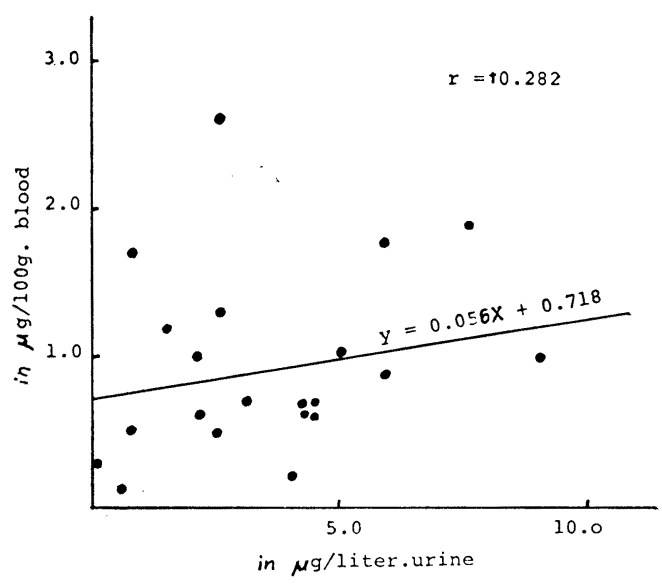

Fig. 2. Relationship between urinary mercury concentration (abscissa) and blood mercury concentration (ordinate) of normal persons by the method presented here.

Fig. 3. Relationship between urinary mercury concentration (abscissa) and blood mercury concentration (ordinate) of mercury workers by the method presented here.

\section{(c) 血中無機水銀測定}

全血 $5 \sim 10 \mathrm{~m} l$ を真空採血管（仁丹テルモ製）で採血 し，科量後，1\%システイン添加 $5 \%$ \%リクロル酢酸液 $20 \mathrm{~m} l$ で除蛋白する.ときどき攪拌し，1時間静置後， 3,500回転で10分間遠沈し, 上清をビーカーに移す. 1 \%システイン添加トリクロル眽酸液各 $20 \mathrm{ml}$ でさらに 2 回沈查から水銀を抽出する. $60 \mathrm{~m} l$ のトリクロル酢酸液 を再蒸溜水で $100 \mathrm{~m} l$ に調整し，尿の場合と同様に測定 する.トリクロル酢酸中には, 微量の水銀が含まれるた
め同一条件での盲検はとくにたいせつである．本法では 血液に基準液を添加した場合，ほぼ $100 \%$ 回収率が得 られるが，測定法を慎重にするために，血液のストック サンブルを用い，標準添加法を同時に実施することがで きればより望ましい。

\section{調 査 結 果}

尿中・血中水銀の正常值を得るため, 水銀の異常暴露 が考えられないわれわれ研究室員ならびに医学生合計 21 


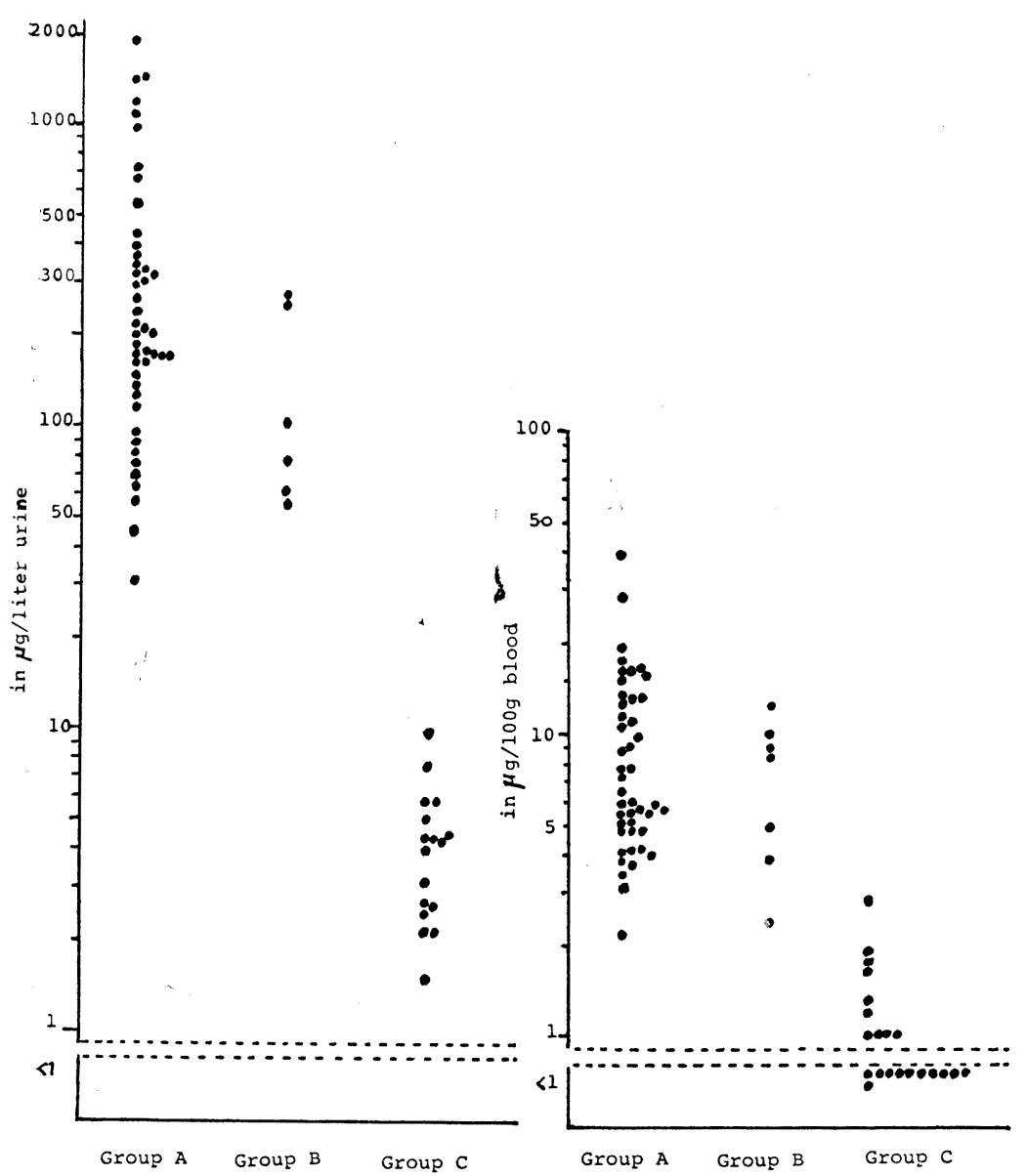

Fig. 4 Comparison of mercury concentration in $\mu \mathrm{g} /$ liter urine, and mercury concentration in $\mu \mathrm{g} / 100 \mathrm{~g}$ blood of workers of three groups.

Group A: Workers of ordinary-type mercurial thermometer factories.

Group B: Workers of special-type mercurial thermometer factories.

Group C: Control.

名について，採尿と採血を同時点に行ない測定した結果 をFig. 2 に示す. スポット尿での尿中水銀值は平均 $3.5 \pm 2.3 \mu \mathrm{g} / l$ (範囲 $0.8 \sim 9.0 \mu \mathrm{g} / l$ ), 血中水銀値には平 均 $0.9 \pm 0.5 \mu \mathrm{g} / 100 \mathrm{~g}$ (範囲 $0.2 \sim 1.9 \mu \mathrm{g} / l$ ) であった. また正常者の尿中水銀值と血中水銀值の相関倸数 $\mathrm{r}=+$ 0.282 と相関関倸はみられなかった。

水銀棒状温度計製造業作業者では，(A)，（B）業者で 尿中水銀值が $1,000 \mu \mathrm{g} / l$ を越えるるのが 14 名中 5 名にみ られ，血中水銀值もとれと対応して高値を示した（A） (C), (D) は家内工業で, 主婦や家族作業者の尿中水銀 值が高值を示した。これらは住宅の一部を作業場として おり, 一見して作業環境は悪く, 施設の改善が必要であ
った.

(A) と (D)の主人は, 血中水銀值それぞれ $37.7 \mu \mathrm{g} /$ $100 \mathrm{~g}, 27.8 \mu \mathrm{g} / 100 \mathrm{~g}$ と高值であったが，(A)の主人は 手指振戦と点断経性言語, 尿中水銀値は $1,049 \mu \mathrm{g} / \mathrm{l}$ であ り, (B)の主人は点断綴性言語, わずかな手指振戦, 尿 蛋白陽性，尿糖陽性があり，スポット尿の水銀は 116 $\mu \mathrm{g} / l$ は低值であった. 尿中水銀排泄は日間変動, 日内 変動が大きいことはすでに知られているところである が，今回の調査結果にもとづき，尿中水銀値と血中水銀 値との相関保数を算出すると $\mathrm{r}=+0.540$ とかなりの相 関がみとめられた (Fig. 3).

尿蛋白陽性は，尿中水銀値 $1,418 \mu \mathrm{g} / l, 200 \mu \mathrm{g} / l, 116$ 
$\mu \mathrm{g} / l$ の 3 名にみられたが, 浮腫や潜血反応など他の腎障 害の所見は得られなかった。 これが水銀暴露に起因する ものであるか否かは, 今後さらに精密検査によって判断 しなければならない。

Fig. 4 は，主として棒状水銀温度計を作る製造業者を $\mathrm{A}$ 群, 特殊型水銀温度計製造業者を $\mathrm{B}$ 群, 対照者の成績 を $\mathrm{C}$ 群として, これら 3 群の尿中水銀値, 血中水銀值に ついて比較したものであり, 棒状水銀温度計業者に高值 を示すものの多いことを示す。

\section{考察}

水銀蒸気を吸入した場合の臓器沈着率は, 腎に最も高 いが, 他の投与方法と異なり, 肺と脳では特異的に増加 する, 臟器排泄率は肺, 腎, 肝などは同程度に速やかで あるが，脳では緩慢である。このため, 慢性暴露では脳 の水銀蓄積は他の藏器よりも生じやすい。

職業性無機水銀中毒は肺からの慢性暴露であるため, 上記の理由で脳など神経組織に水銀が沈着し, 中枢神経 症状が顕著になると考えられている11).

水銀暴露があると尿中水銀排泄が高まるため, 尿中水 銀測定は, 水銀取扱作業者の健康管理汇最も重要な検査 項目の一つである.

尿中水銀值について，Bidstrup ${ }^{6)}$ は，24時間尿で 300 $\mu \mathrm{g} / l$ 以上は中毒症状と関連があるとし, また管理基準 の 1 例として7), $100 \mu \mathrm{g} / l$ 以上を警戒水準, $200 \mu \mathrm{g} / l$ 以 上を危険水準, $300 \mu \mathrm{g} / l$ 以上は中毒症状発現の可能性が あるとされている。

温度計製造業者の尿では，これら管理基準を越える例 が多数みられた。 とくに棒状温度計製造業者にその傾向 が大きかった。これらの工場は，主婦や家族が共同作業 をする場合が多く，家族従業員の尿中・血中水銀値の高 いのも一つの特徵であった.

水銀蒸気は体内で酸化され第 2 水銀塩となり, 毒性を 生ずる.この反応は主に赤血球内で生ずる.

血中水銀檤と臨床症状との関係は, 集団の観察では相 関が認められているが, 個々の場合性例外が多く, 相関 関係は明らかでない，また，血中水銀值と環境濃度の関 係では相関が离るとする報告も多いが，これらの報告か ら計算した尿中水銀陋と血中水銀値との関係は, 尿中水 銀值 $300 \mu \mathrm{g} / l$ 飞対し, 血中水銀值 $7 \mu \mathrm{g} / 100 \mathrm{~m} l$ が対応 するという ${ }^{11)}$.

Goldwater ${ }^{8)}$ は，血中水銀の意義を暴露の指標として より，有害物質の蓄積による生体への影響とし考慮すべ きであるという。
血中水銀の正常値について Goldwater は, $95 \%$ 上限 が $3.0 \mu \mathrm{g} / 100 \mathrm{~m} l$ であるとしているが, 条件を戦格にし た他の報告では $1.0 \mu \mathrm{g} \pm 0.3 \mu \mathrm{g} / 100 \mathrm{~m} l$ であり, 本調查 の正常值は $0.9 \mu \mathrm{g} \pm 0.5 \mu \mathrm{g} / 100 \mathrm{~g}$ であり, 近似した数 值が得られた。

Benning9) の報告した水銀中毒の集団発生では，血中 水銀值は $5.0 \sim 60.0 \mu \mathrm{g} / 100 \mathrm{~g}$, 尿中水銀徝は $100 \sim 3,740$ $\mu \mathrm{g} / l$ であったが, 臨床症状と血中・尿中水銀倠との間に 相関関係は得られなかったという。

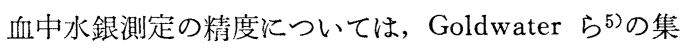
計でも, 報告機関によって, 測定値の分散がかなり相違 している. その要因の一つに測定技術上の問題が重視さ れる。

生物試料中の水銀の測定に, 還元気化一紫外部吸収測 定法の応用は, 手技が簡単で測定䛊差が少なく, 信頼性 が高いため, この調査では本法を用い, 尿中・血中水銀 の正常傎と温度計製造業者の実態調査を実施した。

温度計製造業者のスポット尿中水銀值と同時に採血し た血中水銀値の相関は $\mathrm{r}=0.540$ であった。

被検者中に慢性水銀中毒の症状と思われる軽度手指振 戦, 言語障害を示すものが 2 例あり, ともに自仙中水銀值 は $20 \mu \mathrm{g} / 100 \mathrm{~g}$ 以上であった.

本調查で, 大部分の零細温度計製造業者は, これまで 尿中水銀測定など健康管理に最も必要と思われる検查を 受診していないことが判明したが，さらに水銀充填など 最も危険な仕事をとり扱ら下請業者について，今回の調 查では十分に把握することができなかった。

今後はさらに，この種業者の追跡調査を行ない，予防 対策の指導を行なう必要がある.

稿を終わるにあたり, 東京慈恵会医科大学公衆衛生学教室, 東洋医科大学公衆衛生学教室各位のご助力を深謝いたします.

\section{文献}

1） 後藤 浩, 他: 無機水銀中毒症の 1 例, 臨床神経学, 11 : 708, 1971.

2）原 一郎, 他 : 水銀温度計製造工場に批る水銀中毒の調 查:結果, 大阪府立公衆衛生研究所研究報告, 9-15, 1971,9.

3）鈴木継美：最近経験した水銀中毒, 労働の科学, 17(10)： 23-25, 1962.

4) Magos, L. and Cernik, A. A. : A Rapid Method for Estimating Mercury in Undigested Biological Samples, Brit. J. industr. Med. $26: 144-149,1969$.

5）山口誠哉：日本人の生体内水銀の正常值, 労働の科学, 21 (6) : 36-42, 1966.

6) Bidstrup, P. L., et al. : Chronic Mercury Poisoning in Men Repairing Direct Current Meters, Lancet, 2:856, 1951. 
7）鈴木継美：水銀中毒, 有機水銀中毒（久保田重孝編, 職業 病とその対策), p. 388, 興生社, 東京, 1969 .

8) Goldwater, L. J., et al. : Absorption and Excretion of Mercury in Man. VII. Significance of Mercury in Blood, Arch. Environ. Hlth., 9: 735-741, 1964.

9) Benning, D., Outbreak of Mercury Poisoning in Ohio, Industr. Med. Surg., $27: 354-363,1958$.
10）土屋健三郎 : 再三入院した水銀中毒例（久保田重孝, 土屋 健三郎共著, 職業病の誤診之鑑別診断), p. 23 , 文光堂, 東 京, 1964.

11) Berlin, M. H., et al. : Maximum Allowable Concentrations of Mercury Compounds, Arch. Environ. Hlth., $19: 891-905,1969$. 